\title{
Swelling-Induced Release of Glutamate, Aspartate, and Taurine from Astrocyte Cultures
}

\author{
H. K. Kimelberg, ${ }^{1,2,3}$ S. K. Goderie, ${ }^{1}$ S. Higman, ${ }^{1}$ S. Pang,, ${ }^{1, a}$ and R. A. Waniewski ${ }^{4}$ \\ 'Division of Neurosurgery, 'Department of Pharmacology/Toxicology, IInterdepartmental Program in Neuroscience, Albany \\ Medical College, Albany, New York 12208, and 4Wadsworth Center for Laboratories and Research, New York State \\ Department of Health, Albany, New York 12201
}

\begin{abstract}
Swelling of primary astrocyte cultures by exposing them to hypotonic media caused release of label after the cells had been allowed to accumulate ${ }^{3} \mathrm{H}-\mathrm{L}$-glutamate, ${ }^{3} \mathrm{H}-\mathrm{D}$-aspartate, or ${ }^{3} \mathrm{H}$-taurine. Comparable release of endogenous L-glutamate or taurine, as measured by high-pressure liquid chromatography (HPLC), was also found. Release of label was not affected by treating the cells with cytochalasin $B$, indicating that microfilament polymerization was not significantly involved. Hypotonic-induced release did not appear to principally involve reversal of the $\mathrm{Na}^{+}$-dependent uptake system since increasing external $\mathrm{K}^{+}$to depolarize the cells by replacement of external $\mathrm{Na}^{+}$, thus maintaining isotonic conditions, increased release to a lesser extent. Threo betahydroxyaspartate, a potent ${ }^{3} \mathrm{H}$-L-glutamate uptake blocker, added externally stimulated efflux of ${ }^{3} \mathrm{H}-\mathrm{L}$-glutamate independently of the swelling-induced efflux. Upon restoration of swollen cells to isotonic medium they showed an unimpaired ability to take up ${ }^{3} \mathrm{H}$-L-glutamate. The swelling-induced release of label was inhibited by a number of anion transport inhibitors, one of which has been shown to significantly improve outcome in an experimental brain trauma/ hypoxia model in which astrocyte swelling is an early event.
\end{abstract}

Brain damage during ischemia and other pathological states is now thought to be partly due to the inappropriate release of excitatory amino acids (EAAs) such as L-glutamate and L-aspartate, which, through activation of EAA receptors, causes death of certain neurons (Olney, 1969; Simon et al., 1984; Wieloch, 1985; Choi, 1988; Faden et al., 1989). The origin of the EAAs has been tacitly assumed to be presynaptic nerve endings. However, it has long been known that astrocytes avidly take up glutamate and aspartate by a $\mathrm{Na}^{+}$-dependent mechanism (Hertz, 1979). The glutamate taken up is then converted to glutamine through the action of the astrocyte-specific enzyme, glutamine synthetase (Martinez-Hernandez et al., 1977). This glutamateglutamine pathway constitutes the locus of the small glutamate pool in brain described many years ago (Berl et al., 1961). Release from this pool could occur as a result of the swelling of

\footnotetext{
Received June 26, 1989; revised Oct. 30, 1989; accepted Nov. 20, 1989.

This work was supported by grant NS 23750 to H.K.K. and NS 21299 to R.A.W. We thank E. P. Graham and K. Rebehn for preparing the manuscript.

Correspondence should be addressed to Dr. H. K. Kimelberg, Division of Neurosurgery A-60, Albany Medical College, Albany, NY 12208.

a Permanent address: Institute of Biophysics, Academia Sinica, Beijing, China. Copyright (C) 1990 Society for Neuroscience $0270-6474 / 90 / 051583-09 \$ 02.00 / 0$
}

astrocytes seen in a number of pathological states (Kimelberg and Ransom, 1986), since swelling of isolated cells and many vertebrate and invertebrate tissues is known to lead to the release of taurine, glutamate, aspartate, and other amino acids as part of the process of regulatory volume decrease (RVD) by which swollen cells regain their normal volume (Gilles et al., 1987).

The pathological conditions in which astroglial swelling is observed include experimental (Barron et al., 1988) and human (Castejon, 1980) closed head injury, traumatic (stab wound) brain edema (Gerschenfeld et al., 1959), ischemia (Garcia et al., 1977; Jenkins et al., 1984), hypoglycemia and status epilepticus (Siesjo, 1981), prolonged hypoxia (Yu et al., 1972), acute hypoxia with hypercapnia (Bakay and Lee, 1968), and hepatic encephalopathy (Norenberg, 1981). Astrocytes in vitro have been shown to exhibit RVD after swelling in hypotonic media (Kempski et al., 1983; Kimelberg and Frangakis, 1985; Olson et al., 1986), which is associated with an increased permeability to mannitol (Kimelberg and Goderie, 1988), reversible membrane depolarization (Kimelberg and O'Connor, 1988), and release of ${ }^{3} \mathrm{H}$-taurine (Pasantes-Morales and Schousboe, 1988).

In this study we show that swelling of primary astrocyte cultures in hypotonic media leads to release of label immediately after accumulation of ${ }^{3} \mathrm{H}$-L-glutamate, ${ }^{3} \mathrm{H}$-D-aspartate, and ${ }^{3} \mathrm{H}$ taurine, and release of endogenous glutamate and taurine as measured by IIPLC. Also, this release is inhibited by a number of anion transport blockers, including one compound that we have found significantly improves recovery in an experimental brain trauma/hypoxia model (Cragoe et al., 1986; Kimelberg et al., 1987). In addition, we show that such swelling does not affect reuptake of ${ }^{3} \mathrm{H}$-L-glutamate upon return of the cells to isotonic media, and it is not associated with loss of cell viability as measured by staining with trypan blue, or changes in cell growth. Also, swelling-induced release of ${ }^{3} \mathrm{H}-\mathrm{L}$-glutamate and taurine is not affected by treatment with cytochalasin B.

A preliminary report of this work has been presented (Kimelberg et al., 1989b).

\section{Materials and Methods}

Cell culture. Primary astrocyte cultures were prepared from the cerebral cortices of 1-d-old rats and grown in 12-well multiwells as previously described (Frangakis and Kimelberg, 1984). Cultures were 3-4 weeks old and $\geq 95 \%$ GFAP positive when they were used.

Swelling-induced efflux. For all experiments, cells in 12-well trays were loaded by removing growth media and then washing 4 times with a HEPES buffered media of the following composition in mmoles/liter; $\mathrm{NaCl}, 122 ; \mathrm{KCl}, 3.3 ; \mathrm{CaCl}_{2}, 1.2 ; \mathrm{MgSO}_{4}, 0.4 ; \mathrm{KH}_{2} \mathrm{PO}_{4}, 1.2 ; \mathrm{HEPES}, 25$ adjusted with $\mathrm{NaOH}$ to obtain a pH of 7.4 and glucose 10 . In $\mathrm{Na}^{+}$-free medium basic $N$-methyl-D-glucamine $\left(\mathrm{NMDG}^{+}\right)$was added, and the 
Figure 1. Hypoosmotic-media-induced efflux of label for several labeled compounds from primary astrocyte cultures. The cells were loaded with the appropriate compounds for different times and under varying conditions (see Matcrials and Methods). Relcase is expressed as a percentage of the total label accumulated and represents the release in hypoosmotic minus release in isoosmotic media. The key for the labeled compounds and the osmolarity of the media is as follows. Data represents mean $\pm \mathrm{SEM}, n=4$ wells. This is the same for the data in all the figures unless stated otherwise. Minus $100 \mathrm{~mm} \mathrm{NaCl}$ (dotted lines): $(\bullet--\rightarrow){ }^{3} \mathrm{H}$-taurine, $(\square--\square){ }^{3}$ H-L-glutamate, $(\nabla---\nabla)$ ${ }^{86} \mathrm{Rb}^{+}$. Minus $50 \mathrm{~mm} \mathrm{NaCl}$ (continuous lines $) ;(\diamond-\diamond){ }^{3} \mathrm{H}-\mathrm{D}$-aspartate, $(\square-\square){ }^{3} \mathrm{H}$-L-glutamate, $(0-0)$ ${ }^{3} \mathrm{H}$-taurine, $(\nabla-\nabla){ }^{86} \mathrm{Rb}^{+},(\triangle-\triangle)$ ${ }^{3} \mathrm{H}-5-\mathrm{HT}$. $\mathrm{Na}^{+}$-free medium $(-50 \mathrm{~mm}$ $N$-methyl-D-glucamine $\cdot \mathrm{Cl}(\mathrm{NMDG} \cdot \mathrm{Cl})$ (ㄷ) ${ }^{3} \mathrm{H}$-L-glutamate.

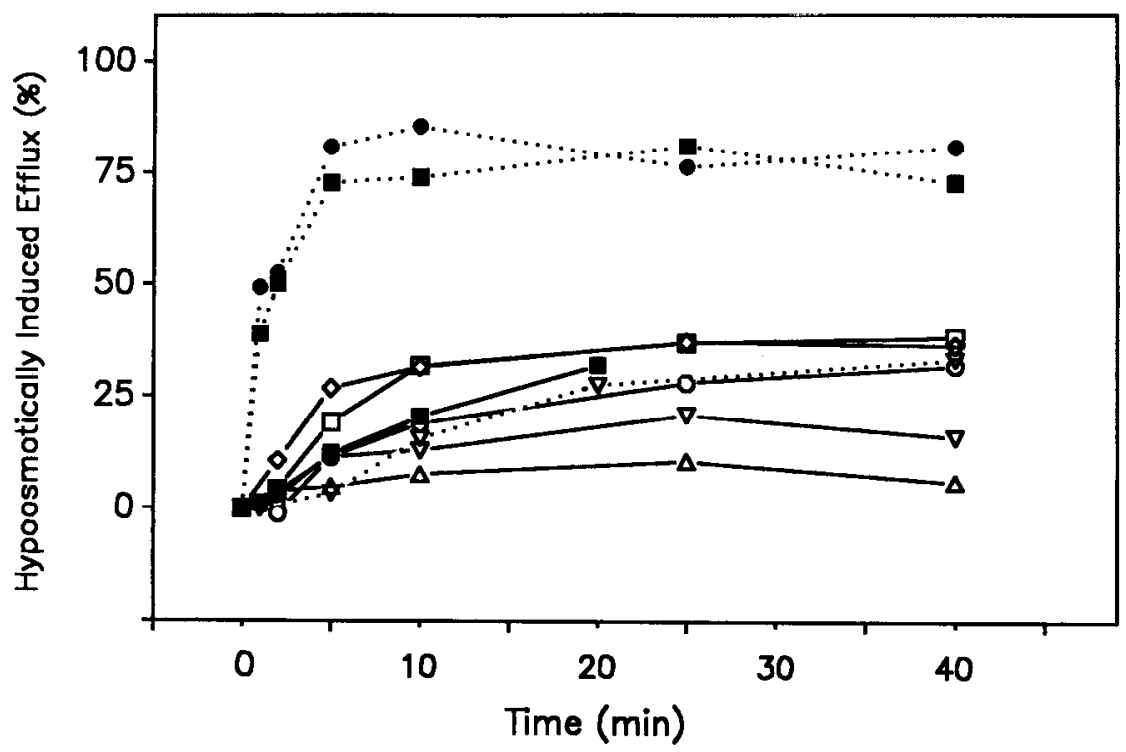

$\mathrm{pH}$ was then adjusted to 7.4 with $\mathrm{HCl}$. The cells were loaded for 30 or 60 min by adding $0.5 \mathrm{ml}$ of warmed $\left(37^{\circ} \mathrm{C}\right) \mathrm{Na}^{+}$-containing buffer, plus the different labeled compounds as follows: $0.4 \mu \mathrm{Ci} \mathrm{L-}\left[3,4,{ }^{3} \mathrm{H}\right]$ glutamic acid (S.A., $69.7 \mathrm{Ci} / \mathrm{mmol}$ ) brought to a tinal concentration of $100 \mu \mathrm{M}$ L-glutamic acid by addition of nonradioactive L-glutamate plus $10 \mathrm{~mm}$ $\mathrm{L}-\mathrm{methionine} \mathrm{sulfoximine} \mathrm{to} \mathrm{inhibit} \mathrm{glutamine} \mathrm{synthetase;} 0.4 \mu \mathrm{Ci} \mathrm{D-}-[2,3$,${ }^{3} \mathrm{H}$ ] aspartic acid (S.A., $26 \mathrm{Ci} / \mathrm{mmol}$ ) plus unlabeled D-aspartate for a final concentration of $100 \mu \mathrm{M}$ aspartate; $0.4 \mu \mathrm{Ci}\left[1,2,-{ }^{-} \mathrm{H}\right]$ taurine (S.A., $35 \mathrm{Ci} / \mathrm{mmol}$ ) plus unlabeled taurine for a final concentration of $50 \mu \mathrm{M}$ taurine; $0.62 \mu \mathrm{Ci} 5$-hydroxy [6-3 $\mathrm{H}]$ tryptamine creatinine sulfate serotonin $(5-\mathrm{HT})(\mathrm{S} . \mathrm{A} ., 12 \mathrm{Ci} / \mathrm{mmol})$ at a final concentration of $0.1 \mu \mathrm{M}$ plus $10^{-4} \mathrm{M}$ pargyline to inhibit monoamine oxidase and $10^{-5} \mathrm{M}$ ascorbate; $2.5 \mu \mathrm{Ci}$ rubidium-86 (S.A., $1-8 \mathrm{mCi} / \mathrm{mg}$ ) used as a tracer for $\mathrm{K}^{+}$. All radioisotopes were from Amersham, except L- $\left[3,4,-{ }^{3} \mathrm{H}\right]$ glutamic acid, which was from New England Nuclear.

After the loading medium was removed, the cells were rapidly washed 3-4 times with warmed $\left(37^{\circ} \mathrm{C}\right)$ isotonic buffered media. Efflux into the final $1 \mathrm{ml}$ of isotonic or hypotonic media was measured by removing $20-\mu 1$ aliquots of the media, and the radioactivity was measured by liquid scintillation counting. In some experiments (Figs. 1, 3, 5, 7) the effluxed radioactivity and the final cell content were added back to obtain the initial cell content and the efflux at increasing times expressed as a percentage of this. In the other experiments the amount of label left in the cells after the efflux period and the cell protein was measured and compared to cells in isotonic media only. After the final sampling the cells were washed 3 times in ice-cold mannitol-wash medium $(0.3 \mathrm{~m}$ mannitol, $10 \mathrm{~mm}$ Tris $\mathrm{Cl}, 0.5 \mathrm{~mm} \mathrm{Ca}\left(\mathrm{NO}_{3}\right)_{2} \cdot 4 \mathrm{H}_{2} \mathrm{O}$, final $\mathrm{pH}$ 7.4). The cells in each well were then solubilized in $1 \mathrm{~N} \mathrm{NaOH}$ and aliquots taken for scintillation counting and protein determination using the Pierce bicinchoninic acid (BCA) reagent as modified for use in monolayer cell cultures (Goldschmidt and Kimelberg, 1989).

Uptake studies. These experiments were done in the same manner as the loading part of the efflux experiments described above. The cells were rapidly washed at the desired times after radioisotope was added with the mannitol wash solution, and the cellular content of isotope and cell protein determined exactly as described above for the efflux experiments.

High-pressure liquid chromatography (HPLC). The cellular contents of endogenous amino acids were determined by adding perchloric acid (PCA) to the cell monolayers immediately after removing the media and washing the cells; $0.3 \mathrm{ml} \mathrm{PCA}(0.4 \mathrm{M})$ was left in contact with the cells for 2-3 min and the 12-well tray was then sonicated with the bottom of the tray immersed in a bath-lype sonicator. The PCA cell extracts were centrifuged and the supernatant neutralized with $1 \mathrm{M} \mathrm{KOH}: \mathrm{KHCO}_{3}$. The amino acid contents of the media were determined by taking $0.2-$ $\mathrm{ml}$ aliquots. An internal standard, s-carboxymethylcysteine (SCMC; 10 $\mu \mathrm{M})$ and $0.01 \%$ sodium azide to prevent bacterial growth was then added to the media samples and the neutralized cell extracts. These samples were then stored at $-70^{\circ} \mathrm{C}$ until analyzed by HPLC. Samples were automatically derivatized with orthophthalaldehyde (OPA) and 2-mercaptoethanol in a borate buffer ( $\mathrm{pH} 10.5$ ). After derivatization, the sample was injected onto a reverse-phase C18 column (Waters Assoc.). The column eluate was passed through a flow cell in a fluorescence spectrophotometer with excitation wavelengths set at $340 \mathrm{~nm}$ and emission set at $450 \mathrm{~nm}$. The fluorescent signal was then transmitted to a computerized integrator and the areas under the peaks calculated and stored. These HPLC chromatographic conditions are modifications of those published by Hill et al. (1979) as described by Spink et al. (1986), with the elution modificd to optimize the scparation of aspartate, glutamate, SCMC, asparagine, glutamine, alanine, and taurine. The limit of detection was $2 \mathrm{pmol}$ in a $10-\mu \mathrm{l}$ sample.

Amino acids were quantified with respect to standard solutions containing the amino acids of interest and SCMC, all at a final concentration of $10 \mu \mathrm{M}$ and prepared identically to samples and run in quadruplicate with each daily analysis of samples.

\section{Results}

\section{Swelling-induced efflux of labeled amino acids}

In Figure 1 we show the effect of reducing medium osmolarity by 100 or $200 \mathrm{mOsm}$ on the release of label after uptake of a number of labeled compounds. The cultures were loaded in normal media and then exposed to normal media or media made hypoosmotic by removal of $\mathrm{NaCl}$ or $\mathrm{NMDG}$ in $\mathrm{Na}^{+}$-free media in which $\mathrm{Na}^{+}$was replaced with NMDG. The results show the accumulative hypotonic-medium-induced efflux as a percentage of the initial total label present at the end of the loading period. Generally, the amount of label released depended on the osmolarity of the medium. For example, for ${ }^{3} \mathrm{H}$-taurine and ${ }^{3} \mathrm{H}$ glutamate release was much greater $(75-80 \%)$ when $100 \mathrm{~mm}$ $\mathrm{NaCl}$ was removed than when $50 \mathrm{~mm} \mathrm{NaCl}$ was removed (25$30 \%$, all measured at $40 \mathrm{~min}$. There were also marked differences between the different compounds. Release of label was similar in the case of ${ }^{3} \mathrm{H}-\mathrm{L}-$ glutamate, ${ }^{3} \mathrm{H}-\mathrm{D}$-aspartate, and ${ }^{3} \mathrm{H}$ taurine. However, hypotonic-medium-induced efflux of ${ }^{86} \mathrm{Rb}^{+}$ was considerably lower, and there was no hypotonic-mediuminduced efflux of labeled ${ }^{3} \mathrm{H}-5-\mathrm{HT}$.

We found that the presence or absence of $\mathrm{Na}^{\prime}$ in the medium had no significant effect on the hypotonic-medium-induced ef- 


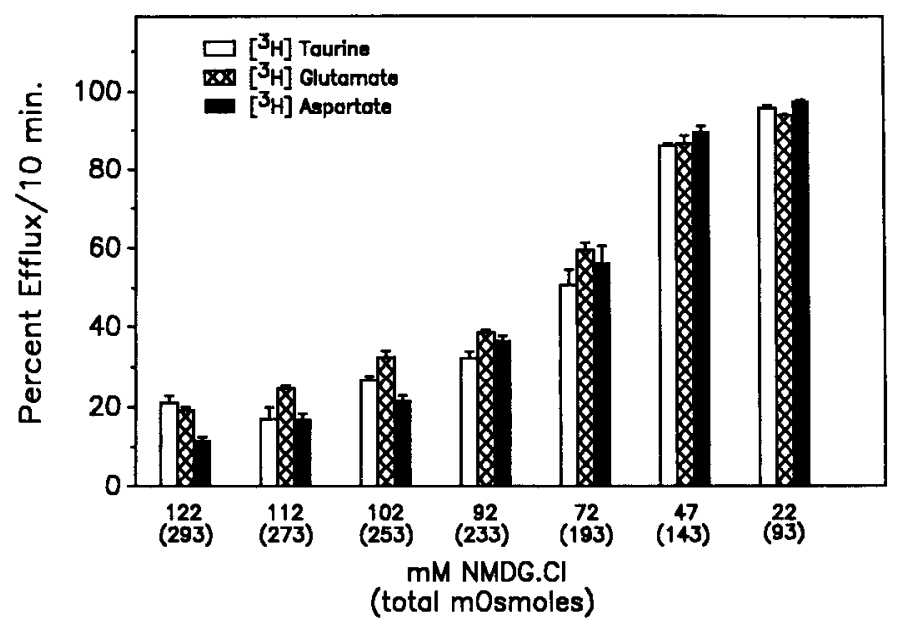

Figure 2. Dose-response curve of the effect of varying media osmolarity on efflux of label for the amino acids shown. Cells were preloaded in normal $\mathrm{Na}^{+}$-containing medium (sce Materials and Methods). The cells were then exposed to $\mathrm{Na}^{+}$-free medium in which the $122 \mathrm{mM} \mathrm{NaCl}$ was replaced by the different concentrations of $N$-methyl-D-glucamine. $\mathrm{Cl}(\mathrm{NMDG} \cdot \mathrm{Cl})$ shown. Efflux was then measured for a 10 -min period by measuring the cell content at the end of this period.

flux, even though it is essential for uptake. We show this for one case in Figure 1; efflux of ${ }^{3} \mathrm{H}-\mathrm{L}$-glutamate into hypotonic $\mathrm{Na}^{+}$-free medium was only slightly lower than in $\mathrm{Na}^{+}$-containing medium. The lack of effect of extracellular $\mathrm{Na}^{+}$in promoting reuptake is probably due to the large dilution of the effluxed material. Basal efflux for ${ }^{3} \mathrm{H}$-L-glutamate and ${ }^{3} \mathrm{H}$-taurine in isotonic medium averaged around 20\% (see data in Figs. 2, 5, 6, 7). Basal efflux of ${ }^{3} \mathrm{H}$-D-aspartate was similar, while for ${ }^{86} \mathrm{Rb}^{+}$ and ${ }^{3} \mathrm{H}-5-\mathrm{HT}$, efflux into isotonic medium was 46 and $62 \%$, respectively, over a $20-\mathrm{min}$ period (data not shown).

In Figure 2 we show a dosc-response relationship for hypotonic-media-induced efflux of label for ${ }^{3} \mathrm{H}$-taurine, ${ }^{3} \mathrm{H}-\mathrm{L}$-glutamate, and ${ }^{3} \mathrm{H}-\mathrm{D}$-aspartate into $\mathrm{Na}^{+}$-free media where all the $\mathrm{NaCl}$ was replaced by varying concentrations of $\mathrm{NMDG} \cdot \mathrm{Cl}$. As can be seen, the efflux of label for all 3 amino acids was similar and increased with decreasing osmolarity.

\section{Swelling-induced eflux of endogenous amino acids}

The identical behavior of the efflux of ${ }^{3} \mathrm{H}$ from D-aspartate or L-glutamate suggests that we are indeed studying efflux of ${ }^{3} \mathrm{H}$ labeled L-glutamate, since D-aspartate is nonmetabolizable. Also, uptake of ${ }^{3} \mathrm{H}$-L-glutamate was only for $30 \mathrm{~min}$, there was no exogenous source of $\mathrm{NH}_{3}$ (Waniewski and Martin, 1986), and we added an inhibitor of glutamine synthetase, L-methionine sulfoximine (Nicklas et al., 1987), as described in Materials and

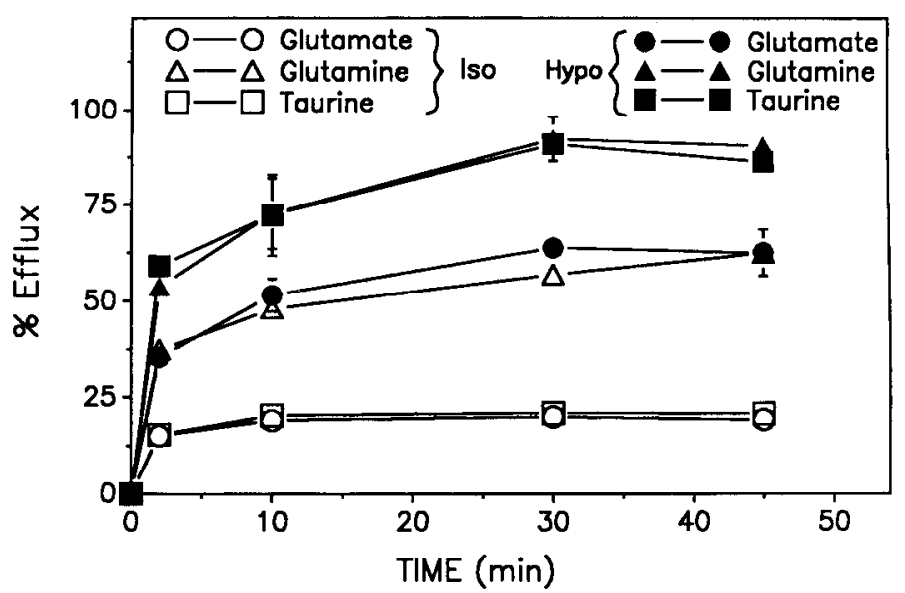

Figure 3. Hypotonic-media-induced efflux of endogenous glutamate, glutamine, and taurine as determined by HPLC. Primary astrocyte cultures were first washed 3 times in normal HEPES buffered media (see Materials and Methods) and then exposed to isotonic $\mathrm{Na}^{+}$-free $\left(\mathrm{Na}^{+}\right.$ replaced with NMDG) or hypotonic ( $-50 \mathrm{~mm} \mathrm{NMDG} \cdot \mathrm{Cl})$ media. Levels of the endogenous amino acids in the media were determined at the times indicated as described in Materials and Methods. These levels were then expressed as an accumulative mean percentage of the level of amino acids present in the same cultures immediately after washing, by determining the content of the amino acids left in the cells after the final sample was removed and adding back this amount to the amounts effluxed (see Materials and Methods).

Methods. ${ }^{3} \mathrm{H}$-taurine is unlikely to be metabolized by these cells (Shain and Martin, 1984). However, in order to confirm that authentic glutamate and taurine is released when the cells swell in hypotonic medium, we also measured efflux of endogenous taurine and glutamate by HPLC, in the absence of $\mathrm{L}$-methionine sulfoximine. These results are shown in Figure 3 , where it can be seen that exposure to $\mathrm{Na}^{+}$-free medium from which 100 mOsm of NMDG $\cdot \mathrm{Cl}$ had becn removed led to increased efflux. At 30 min the efflux into isotonic $\mathrm{Na}^{+}$-free medium was $20 \%$ for both taurine and L-glutamate, and increased to 89 and $63 \%$, respectively, in hypotonic medium $(-50 \mathrm{~mm} \mathrm{NMDG} \cdot \mathrm{Cl})$. This gives a hypotonic-medium-induced efflux of $69 \%$ for taurine and $43 \%$ for L-glutamate. These values correspond reasonably well to the values for the newly accumulated labeled amino acids, except the eflux of endogenous taurine is greater than efflux of endogenous L-glutamate, unlike the results from experiments with the labeled compounds, where the efflux of label is essentially the same. Efflux of endogenous glutamine in hypotonic medium was the same as for taurine, but efflux in isotonic medium was greater, so the hypotonic-medium-induced efflux of glutamine was lower.

In Table 1 we show the endogenous levels in the cells at 45

Table 1. Amino acid levels in cells incubated for $\mathbf{4 5} \mathrm{min}$ in isotonic and hypotonic medium as a percent of initial levels

\begin{tabular}{lcccccc} 
& Aspartate & Asparagine & Alanine & Glutamate & Glutamine & Taurine \\
\hline Isotonic & 113.0 & 95.0 & 58.0 & 83.4 & 28.7 & 77.6 \\
Hypotonic & 65.4 & 46.9 & 32.9 & 36.1 & 7.7 & 8.6 \\
$\Delta \%$ change & -47.6 & -48.1 & -25.1 & -47.3 & -21.0 & -69.0
\end{tabular}




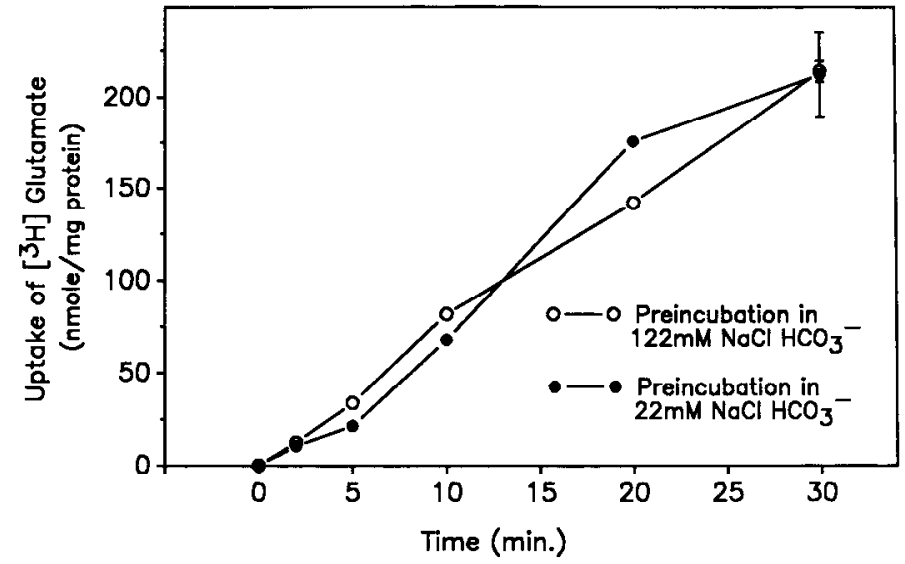

Figure 4. Uptake of ${ }^{3} \mathrm{H}-\mathrm{L}-$ glutamate by cells preincubated in isotonic $(122 \mathrm{~mm} \mathrm{NaCl})$ or hypotonic $(22 \mathrm{~mm} \mathrm{NaCl})$ media for $20 \mathrm{~min}$, as indicated. After this exposure both media were replaced with isotonic media and a time course for the uptake of ${ }^{3} \mathrm{H}$-L-glutamate (see Materials and Methods) was done. In this experiment $25 \mathrm{mM} \mathrm{HCO}_{3}^{-}$replaced HEPES as the buffer. The experiment was done in a $5 \% / \mathrm{CO}_{2} / 95 \%$ air atmosphere using a $\mathrm{CO}_{2}$ incubator.

min of all the amino acids we measured. These values are expressed as a percentage of the levels seen at 0 time. The relative losses in isotonic and hypotonic media for glutamate, glutamine, and taurine mirror the amounts found in the media (see Fig. 3). Aspartate and asparagine levels were very low, but hypotonic-media-induced efflux could be detected. Taurine is clearly the endogenous amino acid present in the highest amounts (see legend to Table 1) and also showed the greatest percentage of hypotonic-media-induced efflux. Based on an intracellular volume of $3.5 \mu \mathrm{l} / \mathrm{mg}$ protein (Kimelberg and Frangakis, 1985; Kimelberg and Goderie, 1988), the endogenous L-glutamate and taurine contents correspond to 15.8 and $113.7 \mathrm{~mm}$, respectively, if both these compounds are freely distributed. The value of $55.4 \mathrm{nmol} / \mathrm{mg}$ protein for glutamate corresponds well to the mean value for glutamate of $67.9 \mathrm{nmol} / \mathrm{mg}$ protein for 3 different astrocytic clones (Cambier and Pessac, 1987).

\section{Effect of swelling on cell viability}

One question that arises about this hypotonic-media-induced efflux is whether it is a result of nonspecific leakage. One argument against this is the selectivity shown in Figure 1 and Table 1. Also, the cells exclude trypan blue during the peak of the swelling ( $1 \mathrm{~min}$ ) and continue to exclude trypan blue during the entire 30-min exposure to hypotonic media (data not shown). We also found that the process was reversible and the cells did not lose important functions. Thus, after exposure to hypotonic medium, cultures replaced in isotonic media were able to take up ${ }^{3} \mathrm{H}$-L-glutamate as well as cultures exposed to isotonic media for the same period of time (Fig. 4). In this one experiment $\mathrm{HCO}_{3}{ }^{-}$replaced HEPES as the buffer (see legend). These data also suggest that glutamate homo-exchange is not a significant component of the uptake of ${ }^{3} \mathrm{H}$-L-glutamate, as also suggested by Hertz et al. (1978), since after swelling almost $90 \%$ of the endogenous glutamate should be lost (see Fig. 2). In addition, the cells continued to divide and grow the same after exposure to hypotonic medium as they did without any such prior cxposure (data not shown).
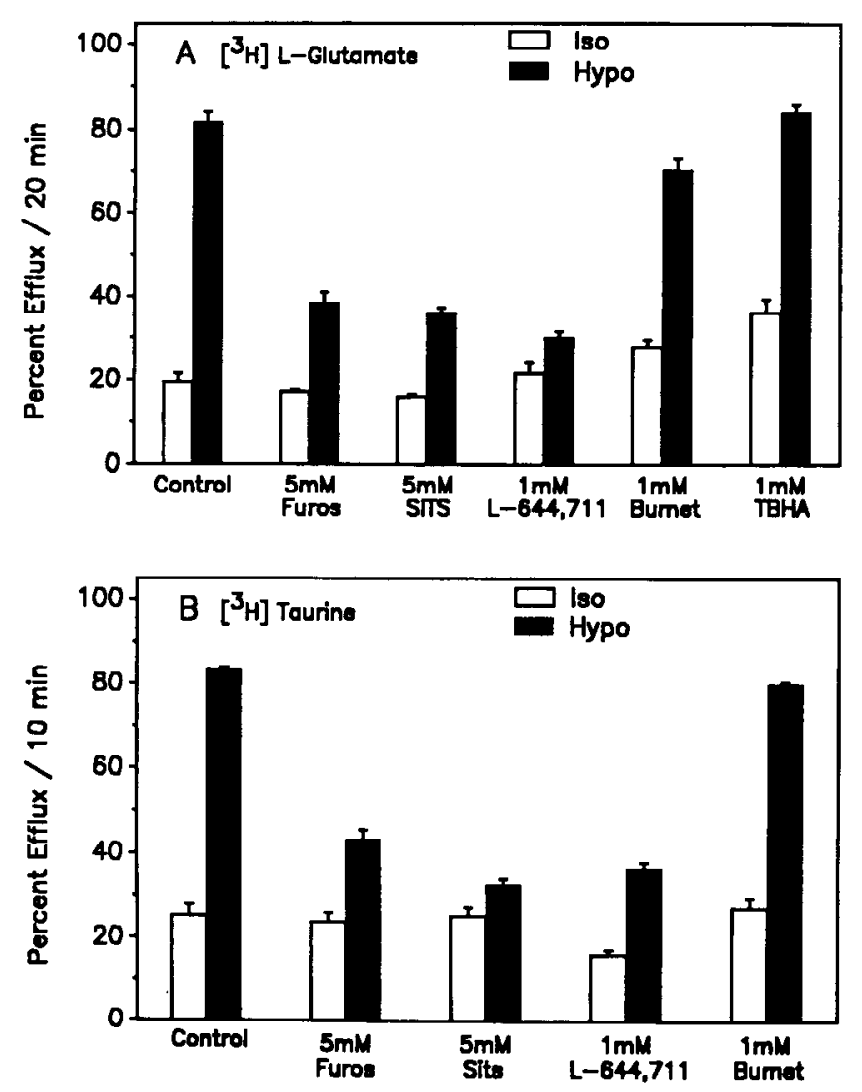

Figure 5. Effect of different anion transport inhibitors on hypotonic $(50 \mathrm{~mm} \mathrm{NMDG} \cdot \mathrm{Cl})$ media-induced efflux of ${ }^{3} \mathrm{H}-\mathrm{L}-$ glutamate $(A)$ and ${ }^{3} \mathrm{H}$-taurine $(B)$ into $\mathrm{Na}^{+}$-free medium. SITS, 4-acetamido-4'-isothiocyanostilbene-2,2'-disulfonic acid; Furos., furosemide; Bumet., bumetanide; L-644,711, $(\mathrm{R}(+)$ [(5,6-dichloro 9a-propyl 2,3,9,9a-tetrahydro 3-oxo-1H fluoren-7-yl)oxy] acetic acid (Cragoe et al., 1986; Kimelberg et al., 1987); $T B H A$, threo beta-hydroxyaspartate. Total effluxed radioactivity was expressed as a percent of the total initial radioactivity present. Inhibitors were added at 0 time when medium was changed from normal isotonic to either $\mathrm{Na}^{+}$-free isotonic or hypotonic medium $\left(\mathrm{Na}^{+}\right.$replaced with $\mathrm{NMDG}^{+}$). Cells were loaded as described in Figure 1. TBHA (see text) is an inhibitor of $\mathrm{Na}^{+}$-dependent $\mathrm{L}$-glutamate uptake in astrocytes (Kimelberg et al., 1989a). All hypotonic-induced effluxes were different from the cfflux in isotonic medium plus inhibitors at levels of significance of $p=0.0001$ or less by 2-tailed $t$ test. For L-644,711 in $A$ and SITS in $B$ the $p$ levels were 0.020 and 0.024 , respectively.

\section{Inhibition by anion transport inhibitors}

The swelling-induced efflux of ${ }^{3} \mathrm{H}-\mathrm{L}$-glutamate and ${ }^{3} \mathrm{H}$-taurine was inhibited by several anion transport blockers (Fig. 5). All the effective inhibitors are inhibitors of the $\mathrm{Cl}^{-} / \mathrm{HCO}_{3}{ }^{-}$anion exchange system, as shown in red blood cells for SITS (Cabantchik et al., 1978), furosemide (Brazy and Gunn, 1976), and L-644,711 (Garay et al., 1986), a fluorenyl derivative of ethacrynic acid (Cragoe et al., 1986). In contrast, bumetanide, a specific inhibitor of the $\mathrm{K}^{+}+\mathrm{Na}^{+}+2 \mathrm{Cl}^{-}$cotransport system (Warnock et al., 1983), was relatively ineffective at the highest concentration we could obtain in aqueous solution. None of the inhibitors had any effect on the initial hypotonic-media-induced swelling, as this involves only inward movement of water.

\section{Swelling-induced efflux appears not to be due to reversal of $\mathrm{Na}{ }^{+}$-dependent uptake}

In the casc of ${ }^{3} \mathrm{H}$-L-glutamatc, we wcre also interested in determining whether part of the efflux involved a reversal of the $\mathrm{Na}^{+}-$ 


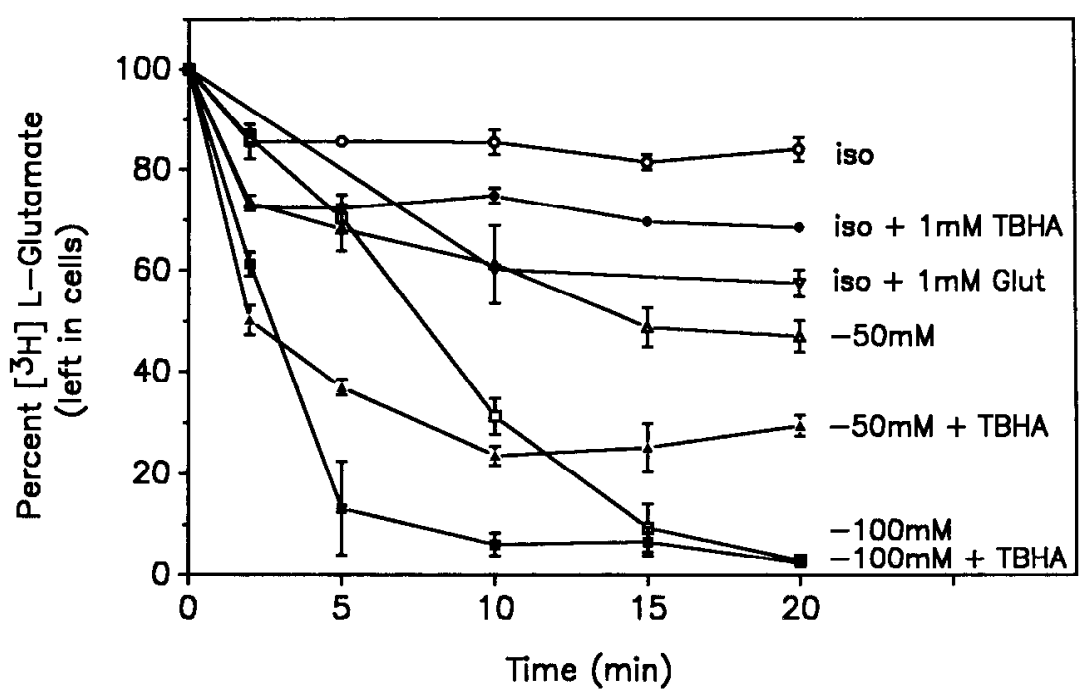

Figure 6. Efflux of ${ }^{3} \mathrm{H}-\mathrm{L}-$ glutamate in isotonic and hypotonic media and the effect of externally added $1 \mathrm{~mm}$ TBHA and L-glutamate at 0 time as indicated. Aliquots of the media were taken at the time indicated and added back to the final cell content and expressed as a percent of the initial level (see Materials and Methods). dependent L-glutamate uptake system, since we make the solution hypotonic by reducing medium $\mathrm{NaCl}$, or we measure efflux into hypotonic $\mathrm{Na}^{+}$-free medium. An effective inhibitor of L-glutamate uptake in primary astrocyte cultures, threo betahydroxyaspartate (TBHA; Kimelberg et al., 1989a), had no effect on efflux of ${ }^{3} \mathrm{H}$ label into hypoosmotic $\mathrm{Na}^{+}$-free medium after the cells were loaded with ${ }^{3} \mathrm{H}-\mathrm{L}$-glutamate (Fig. $5 A$ ). However, this is a competitive blocker of ${ }^{3} \mathrm{H}-\mathrm{L}$-glutamate uptake in astrocytes and we do not know if TBHA has freely entered the cells. Indeed, one interesting feature of this compound is that it stimulated ${ }^{3} \mathrm{H}$-L-glutamate efflux in isotonic media (as shown in Fig. $5 A$ ). This is shown in more detail in Figure 6, where it can be seen that efflux into isotonic media was stimulated by the presence of $1 \mathrm{~mm}$ TBHA. This appears to be by exchange since 1 mM L-glutamate did the same thing, as originally reportcd by Hertz et al. (1978). TBHA also accelerated the efflux in hypotonic media, suggesting that the exchange system operates independently of the swelling-activated system and the 2 processes are additive.

Exposure of the cells to hypotonic media could cause reversal of the $\mathrm{Na}^{+}$-dependent $\mathrm{L}$-glutamate uptake system due to depolarization of the membrane potential (Kimelberg and O'Con- nor, 1988) in conjunction with a reversal of the $\mathrm{Na}^{+}$gradient. In Table 2 we show that the efflux of ${ }^{3} \mathrm{H}$-taurine, ${ }^{3} \mathrm{H}$-L-glutamate, and ${ }^{3} \mathrm{H}-\mathrm{D}$-aspartate was unaffected or affected to a much lesser extent when external $\mathrm{K}^{+}$was increased from 4.5 to $100 \mathrm{~mm}$ by replacement of $\mathrm{Na}^{+}$, which was thus reduced from 122 to 22 $\mathrm{mM}$, thus the isotonicity of the medium was maintained than when the solution was made hypotonic by removal of $100 \mathrm{~mm}$ $\mathrm{NaCl}$ (compare Table 2 with Figs. 1, 2, 5, 7).

\section{Effects of cytochalasin $B$ on swelling-induced efflux}

It has been suggested (Sachs, 1987, 1988) that the microfilament components of the cytoskeleton may mediate the activation of stretch-activated channels (SACs), and by analogy it is possible that the swelling-induced amino acid transport changes could be mediated in the same way. In Figure 7 we show that treatment of the cells with 1,10 , or $30 \mu \mathrm{M}$ cytochalasin B did not affect the efflux of label for ${ }^{3} \mathrm{H}$-taurine or ${ }^{3} \mathrm{H}$-L-glutamate in isotonic medium and also did not alter the hypotonic-medium-induced release. The cells were pretreated with cytochalasin $B$ to obtain maximum morphological changes. Shown in Figure $8 B$ are the marked morphological changes caused by $10 \mu \mathrm{M}$ cytochalasin $\mathrm{B}$ (compare with the normal cultures shown in Fig. 8A).

Table 2. Effect of increased $\mathrm{K}^{+}$and decreased $\mathrm{Na}^{+}$under isotonic conditions on ${ }^{3} \mathrm{H}$-L-glutamate, ${ }^{3} \mathrm{H}-\mathrm{D}-$ aspartate, and ${ }^{3} \mathrm{H}$-taurine efflux

\begin{tabular}{|c|c|c|c|c|}
\hline \multirow{2}{*}{$\begin{array}{l}\text { Composition of media } \\
\text { (changed at } 0 \text { time) }\end{array}$} & \multicolumn{4}{|l|}{ Time (min) } \\
\hline & 2 & 5 & 10 & 20 \\
\hline \multicolumn{5}{|l|}{$4.5 \mathrm{mM} \mathrm{K}^{+} 122 \mathrm{mM} \mathrm{Na}^{+}$} \\
\hline${ }^{3} \mathrm{H}$-L-glutamate & $8.8 \pm 1.72$ & $9.4 \pm 2.18$ & $16.7 \pm 2.04$ & $18.2 \pm 1.41$ \\
\hline${ }^{3} \mathrm{H}$-D-aspartate & $8.9 \pm 1.15$ & $11.0 \pm 1.73$ & $10.6 \pm 0.78$ & $8.1 \pm 0.94$ \\
\hline${ }^{3} \mathrm{H}$-laurine & $6.9 \pm 0.73$ & $7.4 \pm 1.54$ & $8.2 \pm 1.32$ & $7.8 \pm 1.10$ \\
\hline \multicolumn{5}{|l|}{$100 \mathrm{mM} \mathrm{K}^{+} 22 \mathrm{mM} \mathrm{Na}^{+}$} \\
\hline${ }^{3} \mathrm{H}$-L-glutamate & $6.9 \pm 1.28$ & $14.6 \pm 2.60$ & $17.2 \pm 0.96$ & $24.2 \pm 1.50$ \\
\hline${ }^{3} \mathrm{H}$-D-aspartate & $4.8 \pm 1.19$ & $7.4 \pm 0.50$ & $7.6 \pm 0.70$ & $9.8 \pm 0.81$ \\
\hline${ }^{3} \mathrm{H}$-taurine & $19.9 \pm 1.17$ & $15.7 \pm 3.17$ & $23.5 \pm 2.31$ & $28.5 \pm 2.71$ \\
\hline
\end{tabular}

Values represent efflux at times indicated as a percentage of content at 0 time. Cells were loaded with ${ }^{3} \mathrm{H}$-L-glutamate ${ }^{3} \mathrm{H}$-D-aspartate, or ${ }^{3} \mathrm{H}$-taurine (see Materials and Methods). $100 \mathrm{~mm} \mathrm{Na}{ }^{+}$was replaced with $100 \mathrm{~mm} \mathrm{~K}^{+}$where indicated. Values are means \pm SEM. $n$ was 4 wells in all cases. The 100 mм K , 20-min lime for glutamate, and the 10-min time for aspartate were significantly different from $4.5 \mathrm{~mm} \mathrm{~K} \mathrm{~K}^{+}$values at $p=0.01-0.05$ level. For taurine all values were significantly different at the $p<0.001$ level or less, except at the 5 -min time $(p=0.057)$. 


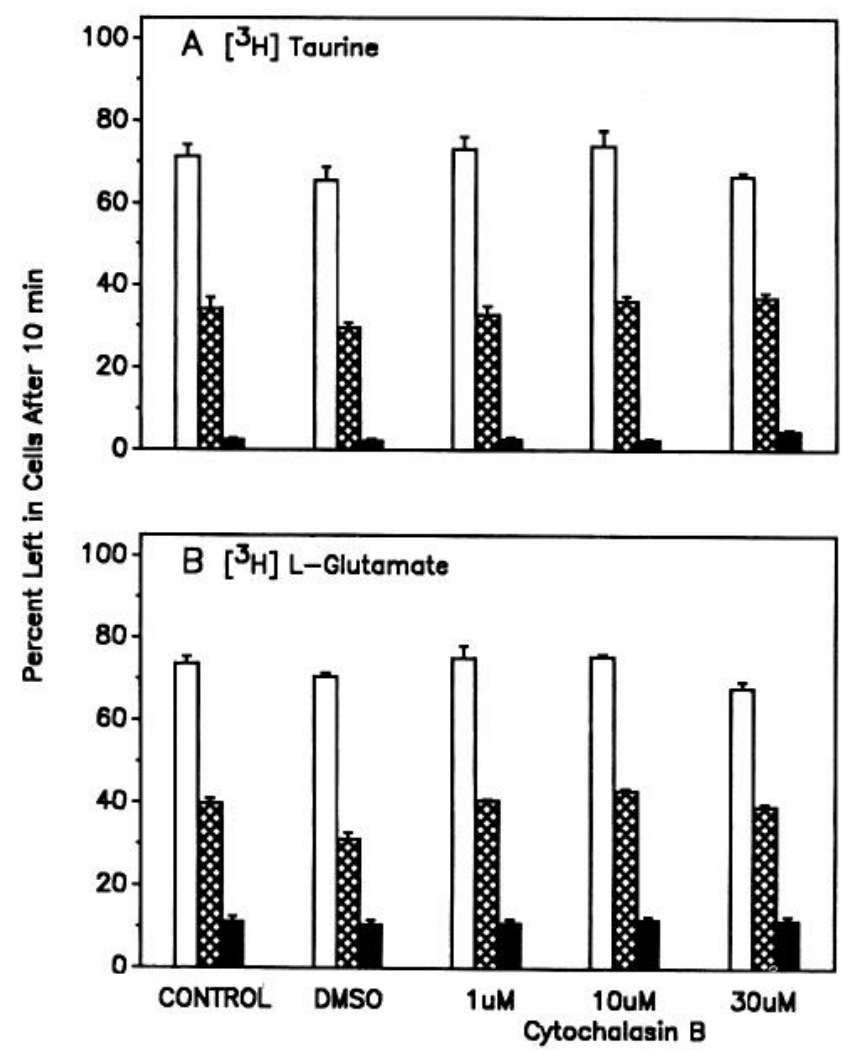

Figure 7. Effect of increasing concentrations of cytochalasin B on the amount of radioactivity left in cells after exposure to $\mathrm{Na}^{+}$-free medium of varying osmolarity; $15 \mu$ l dimethyl sulfoxide (DMSO) alone or different concentrations of cytochalasin B in DMSO up to this maximum volume were first added for a $1-\mathrm{hr}$ preincubation period with ${ }^{3} \mathrm{H}$-taurine or a 30-min preincubation with ${ }^{3} \mathrm{H}$-glutamate in $\mathrm{Na}^{+}$-containing medium. Cytochalasin up to $30 \mu \mathrm{M}$ had no effect on these uptakes. The cultures were then washed in isotonic media (see Materials and Methods) and then exposed to isotonic or hypotonic $\mathrm{Na}^{+}$-free media $\left(\mathrm{NMDG}^{+}\right.$ replacing $\mathrm{Na}^{+}$) also containing DMSO or the different concentrations of cytochalasin B shown in DMSO. Open bars, Isotonic control; stippled bars, $-50 \mathrm{~mm}$ NMDG $\cdot \mathrm{Cl}$; filled bars, $-100 \mathrm{~mm} \mathrm{NMDG} \cdot \mathrm{Cl}$. The percent label remaining associated with the cells was measured after $10 \mathrm{~min}$ and compared to the initial level in the cells after loading.

\section{Discussion}

Swelling-induced efflux of amino acids in astrocytes

There is a considerable body of information that amino acids such as taurine, alanine, glutamate, and aspartate are involved in osmoregulation in euryhaline vertebrates and invertebrates (Gilles, 1987). The amino acids involved can vary from organism to organism and even in different tissues within the same animal. Thus in the common skate (Raja erinacea), taurine and beta alanine are major amino acids in the nucleated red blood cells of this animal, while in its skeletal muscle sarcosine and beta alanine predominate. These amino acids are those which undergo major decreases when the cells or tissue are exposed to hypotonic solutions (Forster and Goldstein, 1979). The transport changes induced by exposing tissue to hypotonic media underlie the processes of RVD, and the need for these processes in euryhaline animals is clear. However, volume regulation is also seen in mammalian cells and the substances released include the major intracellular cations $\mathrm{K}^{+}$and $\mathrm{Cl}^{-}$, as well as amino acids such as taurine and alanine (Grinstein et al., 1984; Hoffmann, 1987).
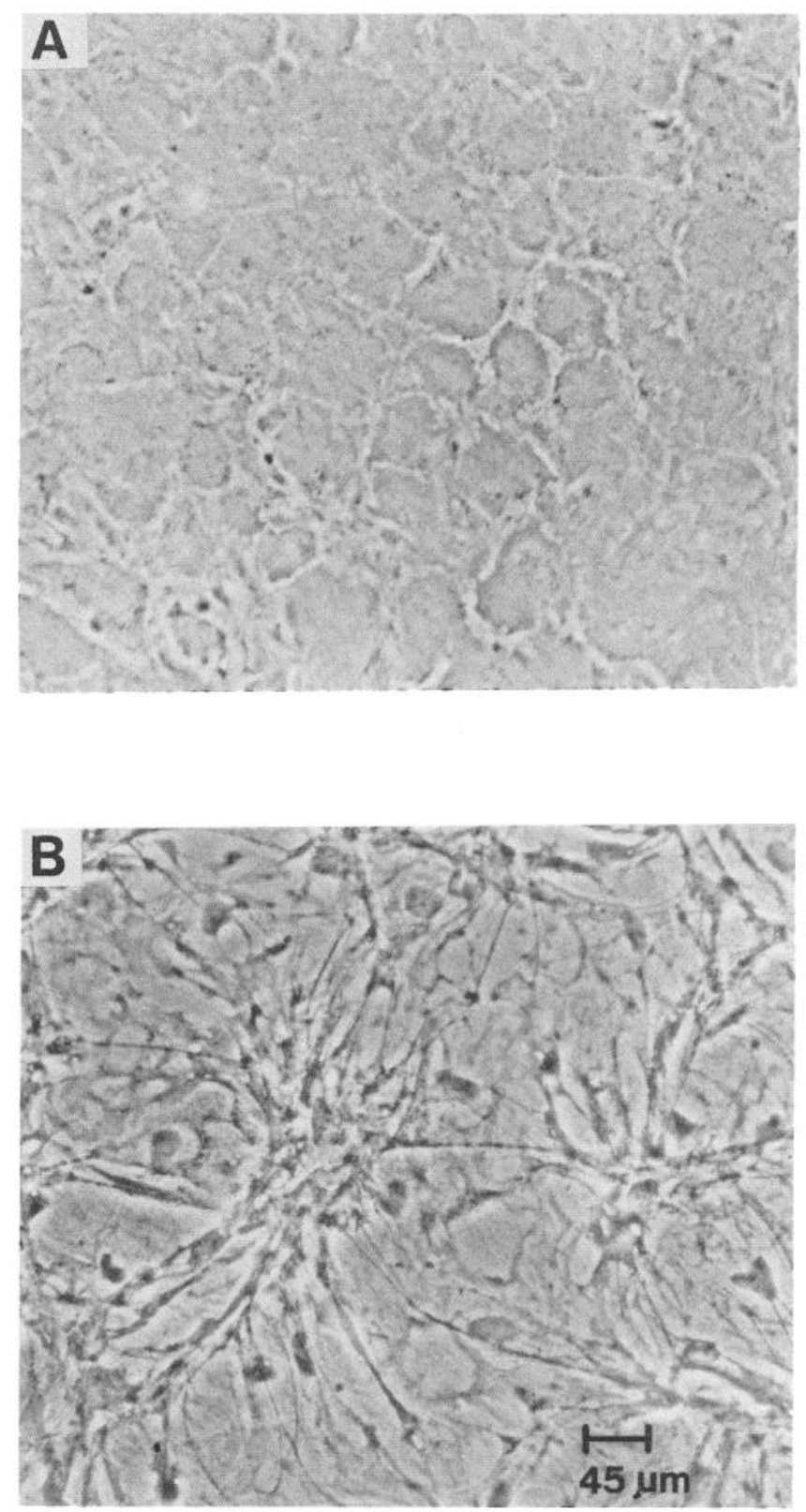

Figure 8. A, Representative phase-contrast micrograph of living cultures exposed to isotonic medium $+15 \mu \mathrm{l}$ DMSO in $1 \mathrm{ml}$ HEPES buffered media (see Materials and Methods) for $30 \mathrm{~min}$. $B$, The same conditions except $10 \mu \mathrm{M}$ cytochalasin B was also present.

The basic observation stimulating our work is that astrocytes are commonly, and usually specifically, swollen in a number of pathological states (see introductory remarks). We are using hypotonic-media-induced swelling of primary astrocyte cultures as a convenient model system for exploring the functional consequences of such swelling. The reasons why astrocytes swell so readily under pathological conditions are still unclear (see $\mathrm{Ki}$ melberg and Ransom, 1986, for a recent discussion of this question). In vivo, significant hypoosmolarity is almost always due to lowered plasma $\mathrm{Na}^{+}$concentrations, i.e., hyponatremia, as encountered in electrolyte imbalance in hospitalized patients. Experimentally, hypoosmolarity leads to loss of taurine, as well as aspartic and glutamic acids, from the brain (Thurston et al., 1975, 1987; Wade et al., 1988; Law, 1989). In a rat model of 
sustained hypoosmolarity (Verbalis and Drutarosky, 1988), the brain water content was kept constant by loss of $\mathrm{K}^{+}, \mathrm{Na}^{+}$, and $\mathrm{Cl}^{-}$. However, half the anion loss was due to unidentified compounds which could have been organic acids. These in vivo results thus correspond to our results for cultured astrocytes exposed to hypoosmolar solutions. Release of ${ }^{3} \mathrm{H}$-taurine has also recently been reported by Pasantes-Morales and Schousboe (1988) for primary astrocyte cultures swollen in hypotonic mcdium. However, these workers found a much smaller release of ${ }^{3} \mathrm{H}$-L-glutamate and ${ }^{3} \mathrm{H}$-D-aspartate, with which the cells had previously been loaded. The reasons for this discrepancy are not clear. Also, since high extracellular $\mathrm{K}^{+}$has been shown to cause swelling of primary astrocyte cultures and is thought to be an important cause of pathological astrocytic swelling in vivo (see Kimelberg and Ransom, 1986), it is of interest that exposure of astrocytes and other glial cultures to medium containing raised $\left[\mathrm{K}^{+}\right]$leads to release of taurine (Martin et al., 1988; Philibert et al., 1988; and see Table 2) under isotonic conditions.

\section{Mechanisms of swelling-induced amino acid release}

The swelling-induced release processes show some degree of selectivity since all the amino acids were released to a greater extent than preloaded ${ }^{86} \mathrm{Rb}^{+}$(an analog for $\mathbf{K}^{+}$), while preloaded ${ }^{3} \mathrm{H}-5-\mathrm{HT}$ was not released at all (Fig. 1). The process was clearly proportional to the degree of swelling (Fig. 2), is not associated with entry of trypan blue, and there was no loss of cell viability (data not shown). Hypotonic-media-induced swelling is also totally reversible in terms of both subsequent uptake of ${ }^{3} \mathrm{H}-\mathrm{L}-$ glutamate in isoosmotic media (Fig. 4) and swelling-induced membrane potential depolarization (Kimelberg and O'Connor, 1988). These data suggest transient changes in specific transport processes, rather than nonspecific "prelytic" opening of nonselective "holes" in the membrane. In further support of a selective process, we have found that a group of compounds that have in common the fact that they will block anion transport processes inhibited the release of the amino acids. Recently, furosemide was reported to block hypotonic-media-induced release of taurine using in vivo microdialysis (Solis et al., 1988).

Reversal of the uptake system appears unlikely to be the dominant mechanism in swelling-induced amino acid efflux, since reduction of external $\mathrm{Na}^{+}$by replacement with $\mathrm{K}^{+}$, maintaining isotonic conditions, caused much smaller effluxes of the labeled amino acids than did removal of comparable amounts of $\mathrm{NaCl}$, resulting in a hypotonic medium (see Table 2).

The swelling-induced transport systems for the amino acids could be mechanistically related to the SACs that have recently been discovered using patch-clamp, single-channel analysis (reviewed in Sachs, 1987, 1988; and Kullberg, 1987). SACs have now been found in a wide variety of cell membranes from bacteria to mammalian cells, including rat primary astrocyte cultures prepared identically to those used in this study (Ding et al., 1989). They are generally activated in either cell-attached or excised membrane patches when negative or positive pressures are applied through the patch pipette. SACs have also been reported to be activated in cell-attached patches when the cells were swollen in hypotonic medium (Christensen, 1987; Sachs, 1988; Falke and Misler, 1989).

It is not clear how mechanical deformations of the membrane are transduced to effect channel openings, but discussions of this have centered on activation of the cytoskeleton, especially actin microfilaments (Sachs, 1987, 1988). Guhary and Sachs (1984) showed that exposure of cultured chick pectoral muscle to $10 \mu \mathrm{M}$ cytochalasin $\mathrm{B}$ for $12 \mathrm{hr}$ changed their morphology from a myotube to a myoball type and also resulted in a large increase in the sensitivity to the applied pressure of the probability of channel opening, but channel activity was not abolished. In our studies cytochalasin B had no effect on efflux of ${ }^{3} \mathrm{H}$-taurine or ${ }^{3} \mathrm{H}$-L-glutamate under either hypotonic or isotonic conditions (Fig. 7). However, cytochalasin B did cause marked morphological changes in our cells (Fig. 8), confirming previous work by Ciesielski-Treska et al. (1982). Thus these data also show that marked cellular and membrane shape changes per se do not affect the swelling-induced efflux.

We found that hypotonic-media-induced swelling of astrocytes causes increased permeability to relatively large compounds such as aspartate and glutamate, although the cells did not take up trypan blue (data not shown), which is a 960-molecular-weight anion. The channels opened in $E$. coli by applying pressure to patches can be permeable to ions as large as glutamate with a large single-channel conductance of $970 \mathrm{pS}$ (Martinac et al., 1987), but the channels opened by this technique in animal cells are generally only permeant to monovalent cations such as $\mathrm{K}^{+}$and divalent cations such as $\mathrm{Ca}^{2+}$ (Guhary and Sachs, 1984; Kullberg, 1987; Lansman et al., 1987; Sachs, 1987, 1988). However, earlier studies on the cell currents produced in crayfish stretch receptors by stretching the muscle showed that large cations such as Tris, tetraethylammonium, and choline could pass (Brown et al., 1978).

SACs are thought to respond to membrane tension, rather than directly to pressure, and a threshold tension of $5 \mathrm{mN} \cdot \mathrm{m}^{-1}$ was needed to activate these channels in yeast (Gustin et al., 1988). We have calculated the tensions generated in astrocytes under the pressures generated by osmotic differences of 100 200 mOsm assuming a sphere with a smooth surface such that volume increases can only be accommodated by stretching the surface membrane. On this basis the membrane tensions generated are almost 2 orders of magnitude higher than the above value. However, it is likely that the volume increases are initially accommodated by an unfolding of the surface membrane (Sarkadi et al., 1984; Parsons et al., 1989). It is possible that only when the volume of astrocytes increases 2- to 3-fold is a threshold tension for SACs generated in the membrane, as proposed for the biconcave to spherical transition for erythrocytes (Davson, 1960), and may account for the lag seen in the dose-response curve shown in Figure 2.

\section{Pathological consequences of astrocytic swelling}

Our studies in vitro suggest that swollen astrocytes may be an additional source of release for $\mathrm{L}$-glutamate and $\mathrm{L}$-aspartate, and perhaps other neurotoxins such as quinolinic acid that are synthetized in astrocytes (Whetsell et al., 1988), which could contribute to the excitotoxin-induced neuronal injury (see introductory remarks). In pathological states release of amino acids may be massive and general, and indeed the failure of volume regulation, as indicated by the persistence of astrocytic swelling under these conditions in situ (see Kimelberg and Ransom, 1986), is perhaps due to the release from intracellular compartments of much of these volume-regulatory substances. Decreases of plasma osmolality of 10 mOsm are seen in normal human pregnancy (Law, 1989) and even larger decreases in hyponatremia are encountered in kidney dialysis (Thurston et al., 1975, 1987) and other hospitalized patients (Verbalis and Drutarosky, 1988). However, whether the changes we have observed with the swelling induced by the larger decreases in osmolarity correspond to 
those seen when astrocytes swell for other reasons, even though the magnitude of the swelling is comparable (Kimelberg and Ransom, 1986), will need further investigation. In spite of such uncertainties, treatment of excitotoxin-mediated CNS injury with agents such as L644,711 might provide a potentially useful additional or alternative therapy to the proposed use of NMDA receptor blockers (Simon et al., 1984; Wieloch, 1985; Choi, 1988). Indeed, we have shown that L644,711 and related compounds lead to improved mortality and morbidity in an experimental closed head injury model (Nelson et al., 1982; Cragoe et al., 1986; Kimelberg et al., 1987) and in a tyramine-induced brain edema model in dogs (Faraj et al., 1988). The parent compound ethacrynic acid was also found to be effective in a preliminary clinical trial (Yen et al., 1979).

\section{References}

Bakay, L., and J. C. Lee (1968) The effect of acute hypoxia and hypercapnia on the ultrastructure of the central nervous system. Brain 91: 697-706.

Barron, K. D., M. P. Dentinger, H. K. Kimelberg, L. R. Nelson, R. S. Bourke, S. Keegan, R. Mankes, and E. J. Cragoe, Jr. (1988) Ultrastructural features of a brain injury model in cat. 1 . Vascular and neuroglial changes and the prevention of astroglial swelling by a fluorenyl(aryloxy) alkanoic acid derivative (L-644,711). Acta Neuropathol. (Berl.) 75: 295-307.

Berl, S., A. Lajtha, and H. Waelsch (1961) Amino acid and protein metabolism. VI. Cerebral compartments of glutamic acid metabolism. J. Neurochem. 7: 186-197.

Brazy, P. C., and R. B. Gunn (1976) Furosemide inhibition of chloride transport in human red blood cells. J. Gen. Physiol. 68: 583-599.

Brown, H. M., D. Ottoson, and B. Rydqvist (1978) Crayfish stretch receptor: An investigation with voltage-clamp and ion-sensitive electrodes. J. Physiol. 284: 155-179.

Cabantchik, Z. I., P. A. Knauf, and A. Rothstein (1978) The anion transport system of the red blood cell. The role of membrane protein evaluated by the use of probes. Biochim. Biophys. Acta 515: 239302.

Cambier, D., and B. Pessac (1987) Free amino-acid content of astroglial cell clones derived from 8-day postnatal mouse cerebella. J. Neurochem. 49: 802-805.

Castejon, O. J. (1980) Electron microscopic study of capillary wall in human cerebral edema. J. Neuropathol. Exp. Neurol. 29: 296-327.

Choi, D. W. (1988) Glutamate neurotoxicity and diseases of the nervous system. Neuron 1: 623-634.

Christensen, O. (1987) Mediation of cell volume regulation by $\mathrm{Ca}^{2+}$ influx through stretch-activated channels. Nature 330:66-68.

Ciesielski-Treska, J., B. Guerold, and D. Aunis (1982) Immunofluorescence study on the organization of actin in astroglial cells in primary cultures. Neuroscience 7: 509-522.

Cragoe, E. J., Jr., O. W. Woltersdorf, Jr., N. P. Gould, A. M. Pietruszkiewicz, C. Ziegler, Y. Sakurai, G. E. Stokker, P. S. Anderson, R. S. Bourke, H. K. Kimelberg, L. R. Nelson, K. D. Barron, J. E. Rose, D. Szarowski, A. J. Popp, and J. P. Waldman (1986) Agents for the treatment of brain edema. 2. [(2,3,9,9a-tetrahydro-3-oxo-9a-substituted-1H-fluoren-7-yl)oxyl alkanoic acids and some of their analogues. J. Med. Chem. 29: 825-841.

Davson, H. (1960) A Textbook of General Physiology, pp. 204-215, J. \& A. Churchill, London.

Ding, J. P., C. L. Bowman, M. Sokabe, and F. Sachs (1989) Mechanical transduction in glial cells: SACS and SICS. Biophys. J. 55: 244a.

Faden, A. I., P. Demediuk, S. S. Panter, and R. Vink (1989) The role of excitatory amino acids and NMDA receptors in traumatic brain injury. Science 244: 798-800.

Falke, L. C., and S. Misler (1989) Activity of ion channels during volume regulation by clonal N1E1 15 neuroblastoma cells. Proc. Natl. Acad. Sci. USA 86: 3919-3923.

Faraj, B. A., E. J. Cragoe, Jr., R. Sarper, M. Camp, and E. Malveaux (1988) Treatment of tryamine-induced brain edema with anion transport inhibitor L-644,711. Life Sci. 42: 2429-2437.
Forster, R. P., and L. Goldstein (1979) Amino acids and cell volume regulation. Yale J. Biol. Med. 52: 497-515.

Frangakis, M. V., and H. K. Kimelberg (1984) Dissociation of neonatal rat brain by dispase for preparation of primary astrocyte cultures. Neurochem. Res. 9: 1689-1698.

Garay, R. P., P. A. Hannaert, C. Nazaret, and E. J. Cragoe, Jr. (1986) The significance of the relative effects of loop diuretics and anti-brain edema agents on the $\mathrm{Na}^{+}, \mathrm{K}^{+}, \mathrm{Cl}^{-}$cotransport system and the $\mathrm{Cl}^{-} /$ $\mathrm{NaCO}_{3}{ }^{-}$anion exchanger. Naunyn-Schmiederberg's Arch. Pharmacol. 334: 202-209.

Garcia, J. H., H. Kalimo, Y. Kamijyo, and B. F. Trump (1977) Cellular events during partial cerebral ischemia. 1. Electron microscopy of feline cerebral cortex after middle-cerebral-artery occlusion. Virchows Arch. B Cell. Path. 25: 191-206.

Gerschenfeld, H. M., F. Wald, J. A. Zadunaisky, and E. D. P. De Robertis (1959) Function of astroglia in the water-ion metabolism of the central nervous system. Neurology 9: 412-425.

Gilles, R. (1987) Volume regulation in cells of euryhaline invertebrates. In Current Topics in Membranes and Transport, Vol. 30, R. Gilles, A. Kleinzeller, and L. Bolis, eds., pp. 205-247, Academic, New York.

Gilles, R., A. Kleinzeller, and L. Bolis, eds. (1987) Current Topics in Membranes and Transport, Vol. 30, Academic, New York.

Goldschmidt, R. C., and H. K. Kimelberg (1989) Protein analysis of mammalian cells in monolayer culture using bicinchoninic assay. Anal. Biochem. 177: 41-45.

Grinstein, S., A. Rothstein, B. Sarkadi, and E. W. Gelfand (1984) Responses of lymphocytes to anisotonic media: Volume-regulating behavior. Am. J. Physiol. 246: C204-C215.

Guhary, F., and F. Sachs (1984) Stretch-activated single ion channel currents in tissue-cultured embryonic chick skeletal muscle. J. Physiol. (Lond.) 352: 685-701

Gustin, M. C., S.-L. Zhou, B. Martinac, and C. Kung (1988) A mechanosensitive ion channel in the yeast plasma membrane. Science 242: 762-765.

Hertz, L. (1979) Functional interactions between neurons and astrocytes I. Turnover and metabolism of putative amino acid transmitters. In Progress in Neurobiology 13, pp. 277-323, Pergamon, Oxford.

Hertz, L., A. Schousboe, N. Boechler, S. Mukerji, and S. Fedoroff (1978) Kinetic characteristics of the glutamate uptake into normal astrocytes in cultures. Neurochem. Res. 3: 1-14.

Hill, D. W., F. H. Walters, T. D. Wilson, and J. D. Stuart (1979) High performance liquid chromatographic determination of amino acids in the picomole range. Anal. Chem. 51: 1338-1341.

Hoffmann, E. K. (1987) Volume regulation in cultured cells. In Current Topics in Membranes and Transport, Vol. 30, R. Gilles, A. Kleinzeller, and L. Bolis, eds., pp. 125-180, Academic, New York.

Jenkins, L. W., D. P. Becker, and T. H. Coburn (1984) A quantitative analysis of glial swelling and ischemic neuronal injury following complete cerebral ischemia. In Recent Progress in the Study and Therapy of Brain Edema, K. G. Go and A. Baethmann, eds., pp. 523-537, Plenum, New York.

Kempski, O., L. Chaussy, U. Gross, M. Zimmer, and A. Baethmann (1983) Volume regulation and metabolism of suspended C6 glioma cells: An in vitro model to study cytotoxic brain edema. Brain Res. 279: 217-228.

Kimelberg, H. K., and M. V. Frangakis (1985) Furosemide- and bumetanide-sensitive ion transport and volume control in primary astrocyte cultures from rat brain. Brain Res. 361: 125-134.

Kimelherg, H. K., and S. K. Goderie (1988) Volume regulation after swelling in primary astrocyte cultures. In Biochemical Pathology of Astrocytes, M. D. Norenberg and L. Hertz, eds., pp. 299-311, Liss, New York.

Kimelberg, H. K., and E. R. O'Connor (1988) Swelling-induced depolarization of astrocyte membrane potentials. Glia $1: 219-224$.

Kimelberg, H. K., and B. R. Ransom (1986) Physiological and pathological aspects of astrocytic swelling. In Astrocytes, Vol. 3, S. Fedoroff and A. Vernadakis, eds., pp. 129-166, Academic, New York.

Kimelberg, H. K., E. J. Cragoe, Jr., L. R. Nelson, A. J. Popp, D. Szarowski, J. W. Rose, O. W. Woltersdorf, Jr., and A. M. Pietruszkiewicz (1987) Improved recovery from a traumatic-hypoxic brain injury in cats by intracisternal injection of an anion transport inhibitor. CNS Trauma 4: 3-14.

Kimelberg, H. K., S. Pang, and D. H. Treble (1989a) Fxcitatory amino 
acid-stimulated uptake of ${ }^{22} \mathrm{Na}^{+}$in primary astrocyte cultures. J. Neurosci. 9: 1141-1149.

Kimelberg, H. K., S. Goderie, and R. Waniewski (1989b) Hypoosmotic media-induced release of amino-acids from astrocytes. Soc. Neurosci. Abstr. 15: 353.

Kullberg, R. (1987) Stretch-activated ion channels in bacteria and animal cell membranes. Trends Neurosci. 10:38-39.

Lansman, J. B., T. J. Hallam, and T. J. Rink (1987) Single stretchactivated ion channels in vascular endothelial cells as mechanotransducers? Nature 325: $811-813$.

Law, R. O. (1989) Effects of pregnancy on the contents of water, taurine, and total amino nitrogen in rat cerebral cortex. J. Neurochem. 53: 300-302.

Martin, D. L., W. Shain, V. Madelian, and B. Seligmann (1988) High $\mathrm{K}^{+}$enhances beta-adrenergic-agonist-stimulated taurine release from glia. Am. Soc. Neurochem. Abstr. 19: 117.

Martinac, B., M. Beuchner, A. H. Delcour, J. Adler, and C. Kung (1987) Pressure-sensitive ion channel in Escherichia coli. Proc. Natl. Acad. Sci. USA 84: 2297-2301.

Martinez-Hernandez, A., K. P. Bell, and M. D. Norenberg (1977) Glutamine synthetase: Glial localization in brain. Science 195: 13561358.

Nelson, L. R., E. L. Auen, R. S. Bourke, K. D. Barron, A. B. Malik, E. J. Cragoe, Jr., A. J. Popp, J. B. Waldman, H. K. Kimelberg, V. V. Foster, W. Creel, and L. Schuster (1982) A comparison of animal head injury models developed for treatment modality evaluation. In Head Injury: Basic and Clinical Aspects, R. G. Grossman and P. L. Gildenberg, eds., pp. 117-127, Raven, New York.

Nicklas, W. I., G. Zeevalk, and A. Hyndman (1987) Interactions between neurons and glia in glutamate/glutamine compartmentation. Biochem. Soc. Trans. 15: 208-210.

Norenberg, M. D. (1981) The astrocyte in liver disease. In Advances in Cellular Neurology, Vol. 2, S. Fedoroff and L. Hertz, eds., pp. 304338, Academic, New York.

Olney, J. W. (1969) Brain lesions, obesity, and other disturbances in mice treated with monosodium glutamate. Science 164: 719-721.

Olson, J. E., R. Sankar, D. Holtzman, A. James, and D. Fleischhacker (1986) Energy-dependent volume regulation in primary cultured cerebral astrocytes. J. Cell. Physiol. 128: 209-215.

Parsons, D. F., R. W. Cole, and H. K. Kimelberg (1989) Shape, size, and distribution of cell structures by 3-D graphics reconstruction and stereology. I. The regulatory volume decrease of astroglial cells. Cell Biophys. 14: 27-42.

Pasantes-Morales, H., and A. Schousboe (1988) Volume regulation in astrocytes: A role for taurine as an osmoeffector. J. Neurosci. Res. 20: 505-509.

Philibert, R. A., K. L. Rogers, A. J. Allen, and G. R. Dutton (1988) Dose-dependent, $\mathrm{K}^{+}$-stimulated efflux of endogenous taurine from primary astrocyte cultures is $\mathrm{Ca}^{2+}$-dependent. J. Neurochem. 51:122126.

Sachs, F. (1987) Baroreceptor mechanisms at the cellular level. Fed. Proc. 46: 12-16.

Sachs, F. (1988) Mechanical transduction in biological systems. CRC Crit. Rev. Biomed. Engineering 16: 141-169.
Sarkadi, B., L. Attisano, S. Grinstein, M. Buchwald, and A. Rothstein (1984) Volume regulation of Chinese hamster ovary cells in anisoosmotic media. Biochim. Biophys. Acta 774: 159-168.

Shain, W. G., and D. L. Martin (1984) Activation of beta-adrenergic receptors stimulates taurine release from glial cells. Cell. Mol. Neurobiol. 4: 191-196.

Siesjo, B. K. (1981) Cell damage in the brain: A speculative synthesis. J. Cereb. Blood Flow Metab. 1: 155-185.

Simon, R. P., J. H. Swan, T. Griffiths, and B. S. Meldrum (1984) Blockade of $N$-methyl-D-aspartate receptors may protect against ischemic damage in the brain. Science 226: 850-852.

Solis, J. M., A. S. Herranz, O. Herreras, J. Lerma, and R. Martin (1988) Does taurine act as an osmoregulatory substance in the rat brain? Neurosci. Lett. 91: 53-58.

Spink, D. C., J. W. Swann, O. C. Snead, R. A. Waniewski, and D. L. Martin (1986) Analysis of aspartate and glutamate in human cerebrospinal fluid by high-performance liquid chromatography with automated precolumn derivatization. Anal. Biochem. 158: 79-86.

Thurston, H. J., R. E. Hauhart, E. M. Jones, and J. L. Ater (1975) Effects of salt and water loading on carbohydrate and energy metabolism and levels of selected amino acids in the brains of young mice. J. Neurochem. 24: 953-957.

Thurston, H. J., R. E. Hauhart, and J. S. Nelson (1987) Adaptive decreases in amino acids (taurine in particular), creatine, and electrolytes prevent cerebral edema in chronically hyponatremic mice: Rapid correction (experimental model of central pontine myelinolysis) causes dehydration and shrinkage of brain. Metab. Brain Dis. 2: $223-241$.

Verbalis, J. G., and M. D. Drutarosky (1988) Adaptation to chronic hypoosmolality in rats. Kidney Int. 34: 351-360.

Wade, J. V., J. P. Olson, F. E. Samson, S. R. Nelson, and T. L. Pazdernik (1988) A possible role for taurine in osmoregulation within the brain. J. Neurochem. 51: 740-745.

Waniewski, R. A., and D. L. Martin (1986) Exogenous glutamate is metabolized to glulamine and exported by rat primary astrocyte cultures. J. Neurochem. 47: 304-313.

Warnock, D. G., R. Greger, P. B. Dunham, M. A. Benjamin, R. A Frizzell, M. Field, K. R. Spring, H. E. Ives, P. S. Aronson, and J. Seifter (1983) Ion transport processes in apical membrane of epithelia. Fed. Proc. 43: 2473-2487.

Whetsell, W. O., Jr., C. Kohler, and R. Schwarcz (1988) Quinolinic acid: A glia-derived excitotoxin in the mammalian central nervous system. In The Biochemical Pathology of Astrocytes, M. D. Norenberg, L. Hertz, and A. Schousboe, eds., pp. 191-202, Liss, New York.

Wieloch, T. (1985) Hypoglycemia-induced neuronal damage prevented by an $N$-methyl-D-aspartate antagonist. Science 230:681-683.

Yen, J. K., R. S. Bourke, A. J. Popp, and L. R. Nelson (1979) Use of ethacrynic acid in the treatment of serious head injury. In Neural Traurna, A. J. Popp, R. S. Bourke, L. R. Nelson, and H. K. Kimelberg, eds., pp. 329-339, Raven, New York.

Yu, M. C., L. Bakay, and J. C. Lee (1972) Ultrastructure of the central nervous system after prolonged hypoxia. II. Neuroglia and blood vessels. Acta Neuropathol. (Berl.) 22: 235-244. 